\title{
\begin{tabular}{|l|l|}
\hline PEDIATRIC & PULMONOLOGY \\
\hline
\end{tabular}
}

\section{What is a clinically meaningful change in exhaled nitric oxide for children with asthma?}

\begin{tabular}{|c|c|}
\hline Journal: & Pediatric Pulmonology \\
\hline Manuscript ID & PPUL-19-0700.R1 \\
\hline Wiley - Manuscript type: & Original Article: Asthma \\
\hline $\begin{array}{r}\text { Date Submitted by the } \\
\text { Author: }\end{array}$ & $n / a$ \\
\hline Complete List of Authors: & $\begin{array}{l}\text { Fielding, Shona; University of Aberdeen, Medical Statistics Team } \\
\text { Pijnenburg, Marielle W.; Erasmus MC - Sophia, Pediatrics } \\
\text { de Jongste, Johan; Erasmus University Medical Center, Pediatrics } \\
\text { Pike, Katharine; University of Southampton Faculty of Medicine, } \\
\text { Respiratory, Critical Care and Anaesthesia Section; University of } \\
\text { Southampton and University Hospital Southampton NHS Foundation } \\
\text { Trust, } \\
\text { Roberts, Graham; University of Southampton } \\
\text { Petsky, Helen; Queensland's Children's Hospital } \\
\text { Chang, Anne; Children's Health Queensland Hospital and Health Service, } \\
\text { Respiratory and Sleep medicine; Menzies School of Health Research, } \\
\text { Children's centre for health research; Queensland Health Centre for } \\
\text { Children's Health Research } \\
\text { Fritsch, Maria; University Children's Hospital } \\
\text { Frischer, Thomas; University Hospital Vienna, Department of Pediatrics } \\
\text { Gergen, Peter; National Institutes of Health, National Institute of Allergy } \\
\text { and Infectious Diseases } \\
\text { Szefler, Stanley; University of Colorado Denver School of Medicine, } \\
\text { Pediatrics } \\
\text { Vermeulen, Françoise; Hôpital Erasme, Université Libre de Bruxelles, } \\
\text { Department of paediatrics } \\
\text { Vael, Robin; University Hospital Antwerp } \\
\text { Turner, Steve; University of Aberdeen, Department of Child Health }\end{array}$ \\
\hline Keywords: & Asthma \& Early Wheeze, Biomarkers, Nitric Oxide (NO) \\
\hline \multicolumn{2}{|l|}{ Other Keywords: } \\
\hline Abstract: & $\begin{array}{l}\text { Introduction. Fractional exhaled nitric oxide (FENO) may be a useful } \\
\text { objective measurement to guide asthma treatment. What remains } \\
\text { uncertain is what change in FENO is clinically significant. } \\
\text { Methods. An individual patient data analysis was performed using data } \\
\text { from seven randomised clinical trials which used FENO to guide asthma } \\
\text { treatment. The absolute and percentage intra-subject change in FENO } \\
\text { measurements over "stable" and also "unstable" three-month periods } \\
\text { were described. } \\
\text { Results. Data were available in } 1112 \text { RCT participants and } \geq 1 \text { stable } \\
\text { period was present for } 665 \text { individuals. The interquartile range (IQR) } \\
\text { and limits of agreement (LOA) for change in absolute FENO among } \\
\text { individuals whose initial FENO was }<50 \text { ppb were }-7 \text { to } 9 p p b \text { and }-43 \text { to }\end{array}$ \\
\hline
\end{tabular}


$50 \mathrm{ppb}$, and for those with initial FENO $\geq 50 \mathrm{ppb}$ IQR was -29 to $17 \mathrm{ppb}$ and LoA was -80 to $76 \mathrm{ppb}$. For percentage change in FENO, the IQR and LoA for individuals whose initial FENO was $<50 \mathrm{ppb}$ were -33 to $51 \%$ and -157 to $215 \%$, and for those with initial FENO $\geq 50 \mathrm{ppb}$ were -33 to $35 \%$ and -159 to $192 \%$. The variation in FENO values for a stable period was similar irrespective of whether it was followed by a stable or unstable period.

Conclusions. Over a three-month period where FENO is initially $<50 \mathrm{ppb}$, a rise of $<10 \mathrm{ppb}$ or of $<50 \%$ (based on IQR) is unlikely to be related to asthma. When FENO is initially $\geq 50 \mathrm{ppb}$ an percentage change of $<50 \%$ (based on IQR) is unlikely to be asthma-related.

\section{SCHOLARONE Manuscripts}


What is a clinically meaningful change in exhaled nitric oxide for children with asthma?

Shona Fielding $\mathrm{PhD}^{1}$, Marielle Pijnenburg $\mathrm{PhD}^{2}$, Johan de Jongste $\mathrm{PhD}^{2}$, Katherine Pike $\mathrm{PhD}^{3,4}$, Graham Roberts $\mathrm{PhD}^{3}$, Helen Petsky $\mathrm{PhD}^{5}$, Anne B Chang $\mathrm{PhD}^{5}$, Maria Fritsch $\mathrm{MD}^{6}$, Thomas Frischer $\mathrm{MD}^{6}$, Stanley Szefler $\mathrm{PhD}^{7}$, Peter Gergen $\mathrm{PhD}^{8}$, Françoise Vermeulen $\mathrm{MD}^{9}$, Robin Vael $M D^{10}$, Steve Turner $\mathrm{MD}^{11}$.

${ }^{1}$ Medical Statistics Team, Institute of Applied Health Sciences, University of Aberdeen, UK

${ }^{2}$ Department of Paediatric Respiratory Medicine and Allergology, Erasmus MC - Sophia Children's Hospital, Rotterdam, Netherlands

${ }^{3}$ Clinical and Experimental Science Academic Unit, University of Southampton, Southampton, UK

${ }^{4}$ Respiratory Critical Care and Anaesthesia group, Institute of Child Health, University College London, UK

${ }^{5}$ Department of Respiratory and Sleep Medicine, Queensland's Children's Hospital, Queensland University of Technology, Brisbane; Child Health Division, Menzies School of Health Research, Charles Darwin University, Darwin, Australia

'University Children's Hospital, Vienna, Austria

${ }^{7}$ Breathing Institute, Children's Hospital Colorado, Department of Pediatrics, University of Colorado School of Medicine, Aurora, Colorado, USA

${ }^{8}$ National Institute of Allergy and Infectious Diseases, Bethesda, MD USA

${ }^{9}$ Department of Paediatrics, Hôpital Erasme, Université Libre de Bruxelles (U.L.B.), Brussels, Belgium 
${ }^{10}$ Department of Paediatrics, Antwerp University Hospital, Antwerp, Belgium

${ }^{11}$ Child Health, University of Aberdeen, UK

Corresponding author: Professor Steve Turner, Child Health, Royal Aberdeen Children's

Hospital, Aberdeen, UK, AB25 2ZG.Tel +44 1224 438470. s.w.turner@abdn.ac.uk

Keywords: Asthma, Child, Monitoring, Exhaled nitric oxide

Running head: What is a meaningful change in $\mathrm{F}_{\mathrm{E}} \mathrm{NO}$ in children? 


\begin{abstract}
Introduction. Fractional exhaled nitric oxide $\left(\mathrm{F}_{\mathrm{E}} \mathrm{NO}\right)$ may be a useful objective measurement to guide asthma treatment. What remains uncertain is what change in $\mathrm{F}_{\mathrm{E}} \mathrm{NO}$ is clinically significant.
\end{abstract}

Methods. An individual patient data analysis was performed using data from seven randomised clinical trials which used $\mathrm{F}_{\mathrm{E}} \mathrm{NO}$ to guide asthma treatment. The absolute and percentage intra-subject change in $\mathrm{F}_{\mathrm{E}} \mathrm{NO}$ measurements over "stable" and also "unstable" three-month periods were described.

Results. Data were available in 1112 RCT participants and $\geq 1$ stable period was present for 665 individuals. The interquartile range (IQR) and limits of agreement (LOA) for change in absolute $\mathrm{F}_{\mathrm{E}} \mathrm{NO}$ among individuals whose initial $\mathrm{F}_{\mathrm{E}} \mathrm{NO}$ was $<50 \mathrm{ppb}$ were -7 to $9 \mathrm{ppb}$ and -43 to $50 \mathrm{ppb}$, and for those with initial $\mathrm{F}_{\mathrm{E}} \mathrm{NO} \geq 50 \mathrm{ppb}$ IQR was -29 to $17 \mathrm{ppb}$ and LoA was -80 to 76ppb. For percentage change in $F_{E} N O$, the IQR and LoA for individuals whose initial $F_{E} N O$ was $<50 p p b$ were -33 to $51 \%$ and -157 to $215 \%$, and for those with initial $\mathrm{F}_{\mathrm{E}} \mathrm{NO} \geq 50 \mathrm{ppb}$ were -33 to $35 \%$ and -159 to $192 \%$. The variation in $\mathrm{F}_{\mathrm{E}} \mathrm{NO}$ values for a stable period was similar irrespective of whether it was followed by a stable or unstable period.

Conclusions. Over a three-month period where $\mathrm{F}_{\mathrm{E}} \mathrm{NO}$ is initially $<50 \mathrm{ppb}$, a rise of $<10 \mathrm{ppb}$ or of $<50 \%$ (based on IQR) is unlikely to be related to asthma. When $\mathrm{F}_{\mathrm{E}} \mathrm{NO}$ is initially $\geq 50 \mathrm{ppb}$ an percentage change of $<50 \%$ (based on IQR) is unlikely to be asthma-related. 


\section{INTRODUCTION}

Asthma is a very common condition and affects millions of children in the UK (1) and the US(2). There is no cure for asthma, but there is effective treatment to control asthma symptoms and reduce exacerbations. Guidelines recommend that asthma treatment is guided by symptoms(3-5), but symptom-reporting and interpretation is subjective and this leads to inconsistent care. There is a need for an objective biomarker to allow greater consistency in asthma treatment (6).

Fractional exhaled nitric oxide $\left(F_{E} N O\right)$ is a surrogate for airway eosinophilia (7) and has potential roles in asthma including diagnosis, treatment stratification, treatment adherence and monitoring airway inflammation (7). A recent Agency for Healthcare Research and Quality comparative effectiveness review of $\mathrm{F}_{\mathrm{E}} \mathrm{NO}$ has summarised evidence which supports a number of potential clinical applications of $\mathrm{F}_{\mathrm{E}} \mathrm{NO}$ in the management of asthma(8). $\mathrm{F}_{\mathrm{E}} \mathrm{NO}$ has many of the characteristics required of an objective tool to monitor allergic asthma over time since it rises before symptoms occur(9-11), falls when asthma treatment is administered $(12,13)$, can be measured with minimal discomfort to the patient and results are available within a few minutes using commercially-available Food and Drink Administration approved apparatus(14). When compared to standard treatment, asthma treatment guided by $\mathrm{F}_{\mathrm{E}} \mathrm{NO}$ measurements is associated with reduced asthma exacerbations, but not improved asthma control(15). There are some key questions which need to be answered before $\mathrm{F}_{\mathrm{E}} \mathrm{NO}$ can be incorporated into the routine longitudinal management of childhood asthma, and current asthma guidelines do not recommend $\mathrm{F}_{\mathrm{E}} \mathrm{NO}$ for monitoring asthma outside specialist clinics(3-5). 
One key question which needs answering is "what change in $\mathrm{F}_{\mathrm{E}} \mathrm{NO}$ is clinically relevant in children?" The American Thoracic Society (ATS) guideline proposes that a change of 10 parts per billion at lower concentrations or $20 \%$ at higher concentrations may have clinical relevance(7), but acknowledge a low level of evidence. However, one study where children with mild asthma and without asthma had repeated measurements of $\mathrm{F}_{\mathrm{E}} \mathrm{NO}$, questioned this ATS recommendation by finding that values may change by as much as $100 \%$ without any clinical change (16). A second study has reported that $\mathrm{F}_{\mathrm{E}} \mathrm{NO}$ values fluctuate between $6 \mathrm{ppb}$ and $40 \mathrm{ppb}$ in children on stable asthma treatment (17).

Our group has pooled the data collected in more than 1000 participants in seven RCTs where $\mathrm{F}_{\mathrm{E}} \mathrm{NO}$ was used to guide asthma treatment (18). This analysis found that a $50 \%$ increase in FeNO between baseline and three months was associated with $11 \%$ increase in odds for poor asthma control six months after baseline(18)but it remains unknown the degree of $\mathrm{F}_{\mathrm{E}} \mathrm{NO}$ variability over stable and unstable periods. Thus, we used individual patient data from the same database of seven RCTs to address the question "What is the variability in $\mathrm{F}_{\mathrm{E}} \mathrm{NO}$ over three months among children with stable asthma?".

\section{METHODS}

\section{Study design}

Authors of published RCTs which used $\mathrm{F}_{\mathrm{E}} \mathrm{NO}$ to guide asthma treatment in children, as previously described (18), provided de-identified data for analyses in this study. All RCTs collected details of $\mathrm{F}_{\mathrm{E}} \mathrm{NO}$ concentrations, asthma control (using different scores) and exacerbation outcome (defined as requiring oral corticosteroid treatment) at each 
assessment. $\mathrm{F}_{\mathrm{E}} \mathrm{NO}$ was measured in all studies in accordance with the American Thoracic Society 2005 guideline(19). Percentage of predicted (\%) FEV 1 was standardised to the Global Lung Initiative reference $(20)$ with the exception of two trials $(21,22)$ where only $\%$ $\mathrm{FEV}_{1}$ standardised to other references was available. Covariates collected at baseline in all trials included: age, gender, height, weight, trial arm, dose of inhaled corticosteroid (ICS, as daily budesonide equivalent dose, BUD), prescribed long acting beta agonist (LABA) or not, prescribed leukotriene receptor agonist (LTRA) or not, and an asthma control score. Institutional ethical approval was provided for each trial which contributed data.

\section{Details of each population}

Fritsch et al(23). In this study, 47 children were recruited from a hospital asthma clinic in Vienna, Austria. Data were collected at six-week intervals over six months.

Peirsman et al(24). Researchers in centres across Belgium recruited 99 participants with persistent asthma attending hospital asthma clinics. Clinical assessments took place every three months over one year.

Petsky et al(25). Children in Australia and Hong Kong were recruited from hospital clinics. There were 63 patients enrolled and clinical assessment took place on eight occasions over twelve months (one, two, three, four, six, eight, ten and twelve months). The ten-month assessment was assigned the "nine month" assessment for the present analysis.

Pijnenburg et al (21). This study was carried out in the Netherlands and 86 patients were recruited and followed up at three-month periods over one year.

Pike et al (22). This was a study carried out in Southampton, UK and 90 patients were recruited and followed up at two-month intervals over twelve months. The twomonth assessment was assigned the "three month" assessment for the analysis, also the ten-month was assigned the "nine month" assessment. 
Szefler et al(26). Children and young adults of African or Hispanic descent and living in inner city areas of ten US cities were recruited. There were 546 participants and data were collected at the following intervals post randomisation: 6 weeks, 14 weeks (used in lieu of three months in the analysis), 22 weeks (used in lieu of six months), 30 weeks (used in lieu of nine months) and 46 weeks (used in lieu of twelve months).

Voorend-van Bergen et al(27). This RCT took place in the Netherlands and 181 participants were recruited. Data from a third arm of the RCT which delivered a web-based intervention were not included in the present analysis. Data were collected at four-month intervals over a year. The four and eight month assessments were respectively assumed to be three and six month assessment for the analysis. There was no equivalent nine-month assessment.

\section{Analysis}

Participants were identified as having a three-month period of stable asthma if they had a period between two successive assessments over three months during which: (i) asthma was controlled at the beginning and end (different RCTs used different scoring systems) (ii) the dose of inhaled corticosteroid (ICS) remained unchanged and (iii) there was no exacerbation requiring oral corticosteroid treatment. Change in $\mathrm{F}_{\mathrm{E}} \mathrm{NO}$ values was expressed as either an absolute difference or percentage difference over a three month period and as either the mean and $95 \%$ limits of agreement (LOA) or median and interquartile range (IQR). Change in $\mathrm{F}_{\mathrm{E}} \mathrm{NO}$ could not be expressed as geometric mean since values can be negative (16). Change in $\mathrm{F}_{\mathrm{E}} \mathrm{NO}$ was described for all individuals and also stratified for individuals with initial values of $<50 \mathrm{ppb}$ and $\geq 50 \mathrm{ppb}$ for comparison with the 
guideline (7) and also for ranges <11ppb, 11-20ppb, 21-30ppb, 31-40ppb and 41-49ppb to allow comparison with data from a study by Cutts et al (16)which recruited children with no asthma and mild asthma(16). One author of the present paper (ST) is data custodian for the study (16) and reanalysed the data for direct comparison between studies. For patients with multiple stable periods, data from only the first stable period was included. To determine whether $\mathrm{F}_{\mathrm{E}} \mathrm{NO}$ values during a stable period were influenced by a subsequent unstable period we described change in $\mathrm{F}_{\mathrm{E}} \mathrm{NO}$ values during; (i) successive stable periods (i.e. when the child's asthma was controlled for three successive assessment, had no change in ICS dose and did not have an exacerbation) and (ii) also a stable followed by an unstable period (i.e. when the child's asthma was controlled for two successive assessments during which there was no change in ICS dose or an exacerbation but where asthma was uncontrolled on the third assessment and where ICS dose remained unchanged). Comparisons we made using Wilcoxon signed rank test.

\section{RESULTS}

Study subjectsData from 1112 participants in seven RCT were analysed (21-27). Participant details at baseline are presented in table one and have also been described elsewhere (18). The mean (SD) participant age was 12.6 (3.1) years and $58 \%$ of participants were male.

\section{Variability of $\mathrm{F}_{\mathrm{E}} \mathrm{NO}$ within stable three months periods}

All stable individuals. There were 251 children who had a total of 260 three-month intervals where asthma was stable. Due to missing $\mathrm{F}_{\mathrm{E}} \mathrm{NO}$ values in 16 individuals, change in $\mathrm{F}_{\mathrm{E}} \mathrm{NO}$ could be calculated in 235 participants with an overall median (IQR) absolute $\mathrm{F}_{\mathrm{E}} \mathrm{NO}$ 
change $-0.5 p p b(-9,10)$, and percentage $\mathrm{F}_{\mathrm{E}} \mathrm{NO}$ change $-2 \%(-33 \%, 50 \%)$. For all stable participants combined, the mean (limits of agreement) for change in absolute $\mathrm{F}_{\mathrm{E}} \mathrm{NO}$ was +2 ppb $(-52,+56)$ and for percentage change $\mathrm{F}_{\mathrm{E}} \mathrm{NO}$ was $+26 \%(-157,+210)$.

Stable and initial $F_{E} N O<50 p p b$. The 185 children with stable asthma and baseline $\mathrm{F}_{\mathrm{E}} \mathrm{NO}<50 \mathrm{ppb}$ had a median (IQR) absolute change in $\mathrm{F}_{\mathrm{E}} \mathrm{NO} 0 \mathrm{ppb}(-7,+9)$ and the median (IQR) percentage change in $\mathrm{F}_{\mathrm{E}} \mathrm{NO}$ was $+2 \%(-33,+51)$, table 2 . The mean $(\mathrm{LoA})$ change in absolute $\mathrm{F}_{\mathrm{E}} \mathrm{NO}$ was $+3(-43,+50)$ and the mean $(\mathrm{LOA})$ percentage change was $+29(-157$, +215), table 2 .

Stable and initial $F_{E} N O \geq 50 p p b$. Where baseline $F_{E} N O$ was $\geq 50 p p b(n=48)$, the median values (IQR) for absolute and percentage change in $\mathrm{F}_{\mathrm{E}} \mathrm{NO}$ were $-7 \mathrm{ppb}(-29,+17)$ and $-10 \%(-33,+35)$ respectively, table 2 . The mean (LoA) for change in absolute $F_{E}$ NO was -2 ppb $(-80,+76)$ and for percentage change $\mathrm{F}_{\mathrm{E}} \mathrm{NO}$ was $+17 \%(-159,+192)$, see table 2

Stable and initial $F_{E} N O$ stratified for comparison with Cutts et al (16). Table 2 presents absolute and percentage change in $\mathrm{F}_{\mathrm{E}} \mathrm{NO}$ expressed as mean (LoA) and median (IQR) using data collected from children with asthma recruited to the RCTs. Data from the study of mostly healthy children by Cutts et al (16) are also presented for comparison.

\section{Variability during consecutive periods of stable asthma followed by stable asthma}

There were 96 individuals with two consecutive periods of stable asthma. The median (IQR) $\mathrm{F}_{\mathrm{E}} \mathrm{NO}$ concentrations during the first and second stable periods were $+1 \mathrm{ppb}$ ($7,+8)$ and $+3 p p b(-8,+10)$; corresponding percentage change $\mathrm{F}_{\mathrm{E}} \mathrm{NO}$ values were $+8(-29,+47)$ 
and $+11(-35,+70)$, see table 3 . Table 3 also presents results after stratification by $<50 \mathrm{ppb}$ and $\geq 50 \mathrm{ppb}$. There was no differences in change in $\mathrm{F}_{\mathrm{E}} \mathrm{NO}$ between the first and second stable periods.

\section{During consecutive periods of stable asthma followed by unstable asthma}

There were 48 individuals identified. The median (IQR) change in absolute $\mathrm{F}_{\mathrm{E}} \mathrm{NO}$ values during stable and unstable periods were $-2(-14,+14)$ and $3(-13,14)$ and percentage change during stable and unstable periods were $-6(-37,+25)$ and $13(-33,+57)$, see table 4 . Table 4 presents results stratified by $<50 \mathrm{ppb}$ and $\geq 50 \mathrm{ppb}$. There was no differences in change in $\mathrm{F}_{\mathrm{E}} \mathrm{NO}$ between the stable and unstable periods.

\section{DISCUSSION}

Fractional exhaled nitric oxide has a number of potential roles in asthma and the focus of the present study was to answer the question "What is a clinically significant change in $\mathrm{F}_{\mathrm{E}} \mathrm{NO}$ for children with asthma?" Our results may be relevant to clinicians when interpreting repeated $\mathrm{F}_{\mathrm{E}} \mathrm{NO}$ measurements, e.g. when making treatment decisions in a child with already-diagnosed asthma. The premise underlying our analysis was that any change in $\mathrm{F}_{\mathrm{E}} \mathrm{NO}$ which occurred in children during a period of stability was not clinically relevant. Our first finding was that when applying a stringent threshold of the LoA (i.e. including 95\% of all values), the variability in $\mathrm{F}_{\mathrm{E}} \mathrm{NO}$ during stability was extremely wide and thus likely to include clinically significant events (i.e. loss of control and/or exacerbation). In contrast when 
applying the more liberal threshold of IQR (i.e including $50 \%$ of all values), the upper limit of variability could be applied clinically. Indeed the upper quartile value for participants with $\mathrm{F}_{\mathrm{E}} \mathrm{NO}<50 \mathrm{ppb}$ was $<10 \mathrm{ppb}$ and consistent with the ATS recommendation (7).

Our second finding was that expressing change in $\mathrm{F}_{\mathrm{E}} \mathrm{NO}$ as percentage change lead to a consistent IQR of between $\pm 50 \%$ for all initial $F_{E} N O$ values. The upper quartile value for $\%$ change where the initial $\mathrm{F}_{\mathrm{E}} \mathrm{NO}$ was $>50 \mathrm{ppb}$ was $35 \%$, but having a "one size fits all" recommendation (i.e. $<50 \%$ is unlikely to be clinically relevant) could be more easily understood by patients and health care staff, and also would facilitate management for individuals whose $\mathrm{F}_{\mathrm{E}} \mathrm{NO}$ is close to $50 \mathrm{ppb}$ (the current dichotomy for different recommendations in the ATS guideline(7)). Our results do not support the ATS "weak" recommendation that a change of $>20 \%$ may be clinically meaningful for children with $\mathrm{F}_{\mathrm{E}} \mathrm{NO} \geq 50 \mathrm{ppb}(7)$.

The IQR and LoA from the present study are consistent with a study where $\mathrm{F}_{\mathrm{E}} \mathrm{NO}$ was measured at two month intervals over a year in children with mild or no asthma, where it was found that initial $\mathrm{F}_{\mathrm{E}} \mathrm{NO}$ values may rise by up to $100 \%$ (16). This consistency is despite important differences between our present study and that of Cutts et al (16), for example our study had a relatively greater number of participants with asthma, higher median $\mathrm{F}_{\mathrm{E}} \mathrm{NO}$ values and $\mathrm{F}_{\mathrm{E}} \mathrm{NO}$ measurements were repeated over a three month period compared to two months. For everyday clinical practice it is more relevant to define clinically relevant changes in $\mathrm{F}_{\mathrm{E}} \mathrm{NO}$ in a population of asthmatic children who are treated with ICS as compared to healthy children or steroid naive children.

Considerable variation in $\mathrm{F}_{\mathrm{E}} \mathrm{NO}$ values over time has also been reported in "natural experiments" in children. For example Huss-Marp et al(28) observed that $\mathrm{F}_{\mathrm{E}} \mathrm{NO}$ values in 
children with mild intermittent asthma with initial $\mathrm{F}_{\mathrm{E}} \mathrm{NO}>17 \mathrm{ppb}$ and attending a summer camp at altitude fell by $50 \%$ over four to six weeks independent of symptoms, and Kaminsky et al (29) found $\mathrm{F}_{\mathrm{E}} \mathrm{NO}$ values fell from 11 to $6 \mathrm{ppb}$ (a $45 \%$ reduction) independent of asthma control among 27 children attending a one week summer camp. Two studies of children with asthma who were sensitised to grass found the $\mathrm{F}_{\mathrm{E}} \mathrm{NO}$ values rose by approximately $50 \%$ during the pollen season $(30,31)$ but asthma symptoms also rose during this time. Barreto et al (32) found that the coefficient of variation in paired $\mathrm{F}_{\mathrm{E}} \mathrm{NO}$ values taken over a one-week period was $3 \mathrm{ppb}$ in eight children treated with ICS. Due to the limited literature describing change in $\mathrm{F}_{\mathrm{E}} \mathrm{NO}$ over time, these studies provide some useful insight into the variability of $\mathrm{F}_{\mathrm{E}} \mathrm{NO}$ but they are limited since some of the variability will be explained by changes in the children's environment.

Within our pooled dataset we were able to explore whether variability in a stable period was different if it was followed by either stability or instability. We found no evidence that repeated measurements of $\mathrm{F}_{\mathrm{E}} \mathrm{NO}$ over three month intervals were influenced by subsequent control, and this is consistent with studies where daily $\mathrm{F}_{\mathrm{E}} \mathrm{NO}$ measurements were made and which observed rising $\mathrm{F}_{\mathrm{E}} \mathrm{NO}$ over only 3-7 days before an exacerbation $(11,17)$. The typical change in $\mathrm{F}_{\mathrm{E}} \mathrm{NO}$ in the studies where daily measurements were obtained was $<50 \%(11,17)$, and the relatively rapid and short-lived peak in $\mathrm{F}_{\mathrm{E}} \mathrm{NO}$ in the context of an asthma exacerbation would indicate that $\mathrm{F}_{\mathrm{E}} \mathrm{NO}$ was not likely to be useful in reducing exacerbation risk, but evidence from RCTs indicates that $\mathrm{F}_{\mathrm{E}} \mathrm{NO}$-guided treatment more effective than standard care in reducing exacerbations (15). Despite the "noisy signal" that is evidenced by the considerable variability in both daily $(11,17)$ and three-monthly (the present study) $\mathrm{F}_{\mathrm{E}} \mathrm{NO}$ measurements, there seems to be sufficient clinically relevant change 
in $\mathrm{F}_{\mathrm{E}} \mathrm{NO}$ over time for $\mathrm{F}_{\mathrm{E}} \mathrm{NO}$-guided treatment to be associated with reduced exacerbations(15).

Our study has a number of limitations. First, the protocols of some of the RCTs included had intervals other than three months between repeated $\mathrm{F}_{\mathrm{E}} \mathrm{NO}$ measurements and this may have added greater variability into repeated measurements. Compared to the study by Cutts et al (16), the IQR for percentage change in the present study was relatively larger but the absolute change was relatively smaller than results so this argues against an interval of two months leading to variation which is substantially greater than for a three month interval. Second, we have no index of treatment adherence, and it is likely that some variation in repeated $\mathrm{F}_{\mathrm{E}} \mathrm{NO}$ measurements was due to incomplete adherence with ICS (12)and/or LTRA (33)treatment. Third the number of participants with stable followed by unstable asthma was relatively small and our analysis comparing intrasubject change in $\mathrm{F}_{\mathrm{E}} \mathrm{NO}$ during these two periods was probably underpowered. A further limitation of our work is that very few individuals were nonatopic and we did not stratify for variability in $\mathrm{F}_{\mathrm{E}} \mathrm{NO}$ by atopic status.

In summary, we interpret our data as showing that a percentage change in $\mathrm{F}_{\mathrm{E}} \mathrm{NO}$ of $<50 \%$ over a three-month period is unlikely to be clinically relevant in a child with controlled asthma whatever their initial $\mathrm{F}_{\mathrm{E}} \mathrm{NO}$ concentration is. $\mathrm{F}_{\mathrm{E}} \mathrm{NO}$ is currently used in clinical practice by many subspecialists in the initial assessment of asthma, endotyping, assessment of adherence and for longitudinal monitoring. Key questions remain to be answered before $\mathrm{F}_{\mathrm{E}} \mathrm{NO}$ might be incorporated into clinical practice to justify a more widespread incorporation into clinical practise, key questions remain to be answered, including "should $\mathrm{F}_{\mathrm{E}} \mathrm{NO}, \mathrm{FEV}_{1}$ and an objective index of treatment adherence all be part of the assessment of children 
with asthma?" And "what specific treatment changes should be guided by changes in $F_{E} N O ? "$ 


\section{REFERENCES}

(1) Asthma UK. Asthma facts and FAQs. 2017; Available at: http://www.asthma.org.uk/asthma-facts-and-statistics. Accessed 08/31, 2017.

(2) Centers for Disease Control and Prevention. Asthma. Most recent data. 2016; Available at: https://www.cdc.gov/asthma/most recent data.htm. Accessed 08/31, 2017.

(3) British Thoracic Society and Scottish Intercollegiate Guidelines Network. SIGN 158. The British Guideline on the Management of Asthma. 2019; Available at: https://www.britthoracic.org.uk/quality-improvement/guidelines/asthma/. Accessed 07/27, 2019.

(4) Global Initiative for Asthma. Global Strategy for Asthma Management and Prevention. 2019; Available at: https://ginasthma.org/gina-reports/. Accessed 07/26, 2019.

(5) National Institute for Health and Care Excellence. Asthma: diagnosis, monitoring and chronic asthma management. 2017; Available at: https://www.nice.org.uk/guidance/ng80. Accessed 01/28, 2018.

(6) Pavord ID, Beasley R, Agusti A, Anderson GP, Bel E, Brusselle G, Cullinan P, Custovic A, Ducharme FM, Fahy JV, Frey U, Gibson P, et al. After asthma: redefining airways diseases. Lancet 2018;391:350-400.

(7) Dweik RA. Boggs PB. Erzurum SC. Irvin CG. Leigh MW. Lundberg JO. Olin AC. Plummer AL. Taylor DR. American Thoracic Society Committee on Interpretation of Exhaled Nitric Oxide Levels (FENO) for Clinical Applications. An official ATS clinical practice guideline:

interpretation of exhaled nitric oxide levels (FENO) for clinical applications. Am J Respir Crit Care Med 2011 Sep 1;184(5):602-615.

(8) Wang Z, Pianosi PT, Keogh KA, Zaiem F, Alsawas M, Alahdab F,Almasri J, Mohammed K, Larrea-Mantilla L, Farah W, et al. The Diagnostic Accuracy of Fractional Exhaled Nitric Oxide Testing in Asthma: A Systematic Review and Meta-analyses. Mayo Clin Proc 2018;93(2):191198.

(9) Pijnenburg MW, Hofhuis W, Hop WC, De Jongste JC. Exhaled nitric oxide predicts asthma relapse in children with clinical asthma remission. Thorax 2005 Mar;60:215-218.

(10) Zacharasiewicz A, Wilson N, Lex C, Erin EM, Li AM, Hansel T, Khan M, Bush A. Clinical use of noninvasive measurements of airway inflammation in steroid reduction in children. Am J Respir Crit Care Med 2005 May 15;171:1077-1082.

(11) van der Valk, R J P., Baraldi E, Stern G, Frey U, de Jongste JC. Daily exhaled nitric oxide measurements and asthma exacerbations in children. Allergy 2012 Feb;67:265-271.

(12) Beck-Ripp J, Griese M, Arenz S, Koring C, Pasqualoni B, Bufler P. Changes of exhaled nitric oxide during steroid treatment of childhood asthma. Eur Respir J 2002 Jun;19(6):10151019. 
(13) Baraldi E, Azzolin NM, Zanconato S, Dario C, Zacchello F. Corticosteroids decrease exhaled nitric oxide in children with acute asthma. J Pediatr 1997 Sep;131:381-385.

(14) Silkoff PE, Carlson M, Bourke T, Katial R, Ogren E, Szefler SJ. The Aerocrine exhaled nitric oxide monitoring system NIOX is cleared by the US Food and Drug Administration for monitoring therapy in asthma. J Allergy Clin Immunol 2004 Nov;114:1241-1256.

(15) Petsky HL, Kew KM, Chang AB. Exhaled nitric oxide levels to guide treatment for children with asthma. Cochrane Database of Systematic Reviews 2016(11):Art. No.: CD011439. DOI: 10.1002/14651858.CD011439.pub2.

(16) Cutts R, Turner S. Longitudinal measurements of exhaled nitric oxide in children-what is a significant change in FE(NO) ?. Pediatr Allergy Immunol 2013;24:540-548.

(17) Stern G, de Jongste J, van der Valk R, Baraldi E, Carraro S, Thamrin C, Frey U. Fluctuation phenotyping based on daily fraction of exhaled nitric oxide values in asthmatic children. $J$ Allergy Clin Immunol 2011;128:293-300.

(18) Fielding S, Pijnenburg M, de Jongste JC, Pike K, Roberts G, Petsky H, Chang AB, Fritsch $\mathrm{M}$, Frischer T, Szefler S, et al. Change in FEV1 and FENO Measurements as Predictors of Future Asthma Outcomes in Children. Chest 2019;155:331-341.

(19) American Thoracic Society, European Respiratory Society. ATS/ERS recommendations for standardized procedures for the online and offline measurement of exhaled lower respiratory nitric oxide and nasal nitric oxide, 2005. Am J Respir Crit Care Med 2005;171:912-930.

(20) Quanjer PH, Stanojevic S, Cole TJ, Baur X, Hall GL, Culver BH, Enright PL, Hankinson JL, Ip MS, Zheng J, et al. Multi-ethnic reference values for spirometry for the 3-95-yr age range: the global lung function 2012 equations. Eur Respir J 2012;40:1324-1343.

(21) Pijnenburg MW, Bakker EM, Hop WC, De Jongste JC. Titrating steroids on exhaled nitric oxide in children with asthma: a randomized controlled trial. Am J Respir Crit Care Med 2005 ;172:831-836.

(22) Pike K, Selby A, Price S, Warner J, Connett G, Legg J, Lucas JS, Peters S, Buckely H, Magier K, et al. Exhaled nitric oxide monitoring does not reduce exacerbation frequency or inhaled corticosteroid dose in paediatric asthma: a randomised controlled trial. Clin Respir J 2013;7:204-213.

(23) Fritsch M, Uxa S, Horak FJ, Putschoegl B, Dehlink E, Szepfalusi Z, Frischer T. Exhaled nitric oxide in the management of childhood asthma: a prospective 6-months study. Pediatr Pulmonol 2006;41:855-862.

(24) Peirsman EJ, Carvelli TJ, Hage PY, Hanssens LS, Pattyn L, Raes MM, Sauer KA, Vermeulen $\mathrm{F}$, Desager KN. Exhaled nitric oxide in childhood allergic asthma management: a randomised controlled trial. Pediatr Pulmonol 2014;49:624-631. 
(25) Petsky HL, Li AM, Au CT, Kynaston JA, Turner C, Chang AB. Management based on exhaled nitric oxide levels adjusted for atopy reduces asthma exacerbations in children: $A$ dual centre randomized controlled trial. Pediatr Pulmonol 2015;50:535-543.

(26) Szefler SJ, Mitchell H, Sorkness CA, Gergen PJ, O'Connor GT, Morgan WJ, Kattan M, Pongracic JA, Teach ST, Bloomberg GR, et al. Management of asthma based on exhaled nitric oxide in addition to guideline-based treatment for inner-city adolescents and young adults: a randomised controlled trial. Lancet 2008;372:1065-1072.

(27) Voorend-van Bergen S, Vaessen-Verberne AA, Brackel HJ, Landstra AM, van den Berg NJ, Hop WC, de Jongste JC, Merkus PJ, Pijnenburg MW. Monitoring strategies in children with asthma: a randomised controlled trial. Thorax 2015;70:543-550.

(28) Huss-Marp J, Kramer U, Eberlein B, Pfab F, Ring J, Behrendt H, Gulyas AF. Reduced exhaled nitric oxide values in children with asthma after inpatient rehabilitation at high altitude. J Allergy Clin Immunol 2007;120:471-472.

(29) Kaminsky DA, Rice AA, Bissonette M, Larose T, Phillips L, Cohen L, Lahiri T, Frankowski B. Exhaled nitric oxide decreases in association with attendance at an asthma summer CAMP. J Asthma 2008;45:415-419.

(30) Roberts G, Hurley C, Bush A, Lack G. Longitudinal study of grass pollen exposure, symptoms, and exhaled nitric oxide in childhood seasonal allergic asthma. Thorax 2004;59:752-756.

(31) Baraldi E, Carra S, Dario C, Azzolin N, Ongaro R, Marcer G, Zachello F. Effect of natural grass pollen exposure on exhaled nitric oxide in asthmatic children. Am J Respir Crit Care Med 1999;159:262-266.

(32) Barreto M, Rennerova Z, Montesano M, Alterio A, Trubacova D, Ronchetti R, Villa MP. Variations in exhaled nitric oxide in children with asthma during a 1-week stay in a mountain village sanatorium. J Asthma 2008;45:453-458.

(33) Montuschi P, Mondino C, Koch P, Barnes PJ, Ciabattoni G. Effects of a leukotriene receptor antagonist on exhaled leukotriene E4 and prostanoids in children with asthma. J Allergy Clin Immunol 2006;118:347-353. 
Table 1. This table presents characteristics of study participants at their baseline visit for each study and also summarises characteristics across all studies combined. ${ }^{*}$ Controlled status was determined from questionnaires used in each study.

\begin{tabular}{|c|c|c|c|c|c|c|c|c|c|}
\hline & & $\begin{array}{l}\text { Fritsch(Fritsc } \\
\text { h et al., 2006) }\end{array}$ & $\begin{array}{l}\text { Peirsman(Pei } \\
\text { rsman et al., } \\
\text { 2014) }\end{array}$ & $\begin{array}{l}\text { Petsky(Petsk } \\
\text { y, Helen L. et } \\
\text { al., 2015) }\end{array}$ & $\begin{array}{l}\text { Pijnenburg(Pi } \\
\text { jnenburg, } \\
\text { Marielle W. } \\
\text { et al., 2005) }\end{array}$ & $\begin{array}{l}\text { Pike(Pike et } \\
\text { al., 2013) }\end{array}$ & $\begin{array}{l}\text { Szefler(Szefle } \\
\text { r et al., 2008) }\end{array}$ & $\begin{array}{l}\text { Voorend-van } \\
\text { Bergen(Voor } \\
\text { end-van } \\
\text { Bergen S et } \\
\text { al., 2015) }\end{array}$ & $\begin{array}{l}\text { All populations } \\
\text { combined }\end{array}$ \\
\hline \multicolumn{2}{|c|}{$\%$ male (number/all participants } & $60 \%(28 / 47)$ & $67 \%(66 / 99)$ & $49 \%(31 / 63)$ & $65 \%(56 / 86)$ & $57 \%(51 / 90)$ & $\begin{array}{c}53 \% \\
(288 / 546) \\
\end{array}$ & $\begin{array}{c}68 \% \\
(123 / 181) \\
\end{array}$ & $\begin{array}{c}58 \% \\
(643 / 1112) \\
\end{array}$ \\
\hline \multicolumn{2}{|c|}{ Mean age (SD), y } & $11.5(3.1)$ & $10.7(2.1)$ & $10.0(3.2)$ & $12.3(2.8)$ & $10.9(2.6)$ & $14.4(2.1)$ & $10.2(3.0)$ & $12.6(3.1)$ \\
\hline \multicolumn{2}{|c|}{ Median $\mathrm{F}_{\mathrm{E}} \mathrm{NO}$ (IQR), ppb } & $\begin{array}{c}34(18.6 \\
58.6) \\
n=46\end{array}$ & $\begin{array}{c}31(14,69) \\
n=49\end{array}$ & $\begin{array}{c}26(12.2 \\
47.5) n=61\end{array}$ & $\begin{array}{c}32(16.6 \\
52.5) n=86\end{array}$ & $\begin{array}{c}26(10,48) \\
\quad n=90\end{array}$ & $\begin{array}{c}20(11.2 \\
40.6) \\
n=546\end{array}$ & $\begin{array}{c}18(10.2 \\
30.4) n=179\end{array}$ & $\begin{array}{c}22(11.6,43.0) \\
n=1057\end{array}$ \\
\hline \multicolumn{2}{|c|}{ Mean $\%$ predicted FEV ${ }_{1}(\mathrm{SD})$} & $\begin{array}{c}93.5(15.7) \\
n=47\end{array}$ & $\begin{array}{c}91.4(15.7) \\
\mathrm{n}=98\end{array}$ & $\begin{array}{c}90.7(15.6) \\
n=54\end{array}$ & $\begin{array}{c}97.5(17.5) \\
n=86\end{array}$ & $\begin{array}{c}89.2(14.3) \\
n=90\end{array}$ & $\begin{array}{c}90.9(16.6) \\
n=546\end{array}$ & $\begin{array}{c}93.8(13.0) \\
n=157\end{array}$ & $\begin{array}{c}93.5(18.1) \\
n=1078\end{array}$ \\
\hline \multicolumn{2}{|c|}{$\%$ with positive skin prick test } & $\begin{array}{l}\text { Inclusion } \\
\text { criterion }\end{array}$ & $\begin{array}{l}\text { Inclusion } \\
\text { criterion }\end{array}$ & $\begin{array}{c}38 \% \\
(24 / 63)\end{array}$ & $\begin{array}{l}\text { Inclusion } \\
\text { criterion }\end{array}$ & $\begin{array}{c}76 \% \\
(68 / 90)\end{array}$ & $\begin{array}{c}88 \% \\
(467 / 531)\end{array}$ & $\begin{array}{l}\text { Inclusion } \\
\text { criterion }\end{array}$ & $\begin{array}{c}89 \% \\
(972 / 1097)\end{array}$ \\
\hline \multirow[t]{3}{*}{$\begin{array}{l}\text { Asthma } \\
\text { medicatio } \\
\mathrm{n}\end{array}$} & $\begin{array}{l}\text { Median dose of } \\
\text { inhaled } \\
\text { corticosteroids } \\
\text { (IQR) }\end{array}$ & $\begin{array}{l}400 \\
(0,800)\end{array}$ & $\begin{array}{l}320 \\
(200,400)\end{array}$ & $\begin{array}{l}400 \\
(250,500)\end{array}$ & $\begin{array}{l}800 \\
(400,1000)\end{array}$ & $\begin{array}{l}800 \\
(400,1000)\end{array}$ & $\begin{array}{l}1000 \\
(400,2000)\end{array}$ & $\begin{array}{l}400 \\
(400,800)\end{array}$ & $\begin{array}{l}400 \\
(400,1000)\end{array}$ \\
\hline & \% prescribed LTRA & $28 \%(13 / 47)$ & $60 \%(59 / 99)$ & $10 \%(6 / 58)$ & $0 \%(0 / 86)$ & $51 \%(46 / 90)$ & $15 \%(80 / 546)$ & $13 \%(23 / 181)$ & $\begin{array}{l}21 \% \\
(227 / 1107)\end{array}$ \\
\hline & $\%$ prescribed LABA & $38 \%(18 / 47)$ & $32 \%(32 / 99)$ & $67 \%(39 / 58)$ & $38 \%(33 / 86)$ & $76 \%(68 / 90)$ & $\begin{array}{l}66 \% \\
(360 / 546)\end{array}$ & $46 \%(84 / 181)$ & $\begin{array}{l}57 \% \\
(634 / 1107)\end{array}$ \\
\hline \multicolumn{2}{|c|}{ Controlled* } & $49 \%(23 / 47)$ & $75 \%(49 / 65)$ & $72 \%(41 / 57)$ & $57 \%(44 / 77)$ & $97 \%(87 / 90)$ & $\begin{array}{l}80 \% \\
(421 / 528)\end{array}$ & $\begin{array}{l}67 \% \\
(122 / 181)\end{array}$ & $\begin{array}{l}75 \% \\
(787 / 1045)\end{array}$ \\
\hline
\end{tabular}

$\mathrm{SD}=$ standard deviation, $\mathrm{F}_{\mathrm{E}} \mathrm{NO}=$ fractional exhaled nitric oxide, $\mathrm{ppb}=$ parts per billion, $\mathrm{FEV}_{1}=$ Forced exhaled volume in one second,

$\mathrm{IQR}=$ interquartile range, LTRA=leukotriene receptor antagonist, LABA=long acting beta agonist 
Table 2. Median and interquartile range (IQR) of absolute and percentage difference in two $\mathrm{F}_{\mathrm{E}} \mathrm{NO}$ measurements made over an interval of three months during which asthma symptoms and inhaled corticosteroid treatment remained stable and there was no asthma exacerbation. The numbers in italics are from a reanalysis of the data in the study by Cutts et al (16) where data collected over a two month period are available (insufficient data were available for meaningful analysis of 31-40ppb and 41-49ppb groups.

\begin{tabular}{|c|c|c|c|c|}
\hline & $\begin{array}{l}\text { Initial } \mathrm{F}_{\mathrm{E}} \mathrm{NO} \\
\text { measurement }\end{array}$ & $\mathrm{N}$ & $\begin{array}{l}\text { Median (IQR) difference in } \mathrm{F}_{\mathrm{E}} \mathrm{NO} \\
\text { measurements over a stable three- } \\
\text { month period } \\
\text { (values in italics from Cutts et al) }\end{array}$ & $\begin{array}{c}\text { Mean difference [limits of agreement] } \\
\text { in } \mathrm{F}_{\mathrm{E}} \mathrm{NO} \text { measurements over a stable } \\
\text { three-month period } \\
\text { (values in italics from Cutts et al) }\end{array}$ \\
\hline \multirow[t]{7}{*}{$\begin{array}{l}\text { Absolute } \mathrm{F}_{\mathrm{E}} \mathrm{NO} \\
\text { concentration }\end{array}$} & $<11 \mathrm{ppb}$ & $\begin{array}{l}51 \\
69\end{array}$ & $\begin{array}{l}+2(-3,+5) \\
+1(0,+3)\end{array}$ & $\begin{array}{c}+1[-19,+21] \\
+1[-6,+9]\end{array}$ \\
\hline & $11-20 \mathrm{ppb}$ & $\begin{array}{l}59 \\
41\end{array}$ & $\begin{array}{r}0(-6,+10) \\
-1(-5,+4)\end{array}$ & $\begin{array}{l}+4[-37,+45] \\
+2[-18,+21]\end{array}$ \\
\hline & $21-30 \mathrm{ppb}$ & $\begin{array}{l}41 \\
11\end{array}$ & $\begin{array}{c}3(-9,+17) \\
-3(-13,+5)\end{array}$ & $\begin{array}{l}+8[-50,+65] \\
+3[-41,+46]\end{array}$ \\
\hline & $31-40 \mathrm{ppb}$ & 18 & $-5(-12,+10)$ & $-2[-53,+48]$ \\
\hline & 41-49 ppb & 16 & $-7(-19,+25)$ & $+3[-78,+84]$ \\
\hline & $<50 \mathrm{ppb}$ & $\begin{array}{l}185 \\
129 \\
\end{array}$ & $\begin{array}{l}0(-7,+9) \\
0(-3,4)\end{array}$ & $\begin{array}{c}+3[-43,+50] \\
-15[-77,+46]\end{array}$ \\
\hline & $>=50 \mathrm{ppb}$ & $\begin{array}{c}48 \\
8\end{array}$ & $\begin{array}{l}-7(-29,+17) \\
-10(-29,+7)\end{array}$ & $\begin{array}{c}-2[-80,+76] \\
-18[-90,+52]\end{array}$ \\
\hline \multirow[t]{3}{*}{$\begin{array}{l}\text { Percentage change in } \\
\qquad F_{E} N O\end{array}$} & $<11 p p b$ & $\begin{array}{l}51 \\
69\end{array}$ & $\begin{array}{c}+18(-27,+59) \\
+11(0,+67)\end{array}$ & $\begin{array}{l}+38[-151,+228] \\
+32[-130,+194]\end{array}$ \\
\hline & $11-20 \mathrm{ppb}$ & $\begin{array}{l}59 \\
41 \\
\end{array}$ & $\begin{array}{l}+1(-37,+64) \\
-7(-36,+31) \\
\end{array}$ & $\begin{array}{l}+30[-170,+231] \\
+11[-118,+141]\end{array}$ \\
\hline & $21-30 \mathrm{ppb}$ & 41 & $18(-32,+49)$ & $+27[-155,+210]$ \\
\hline
\end{tabular}




\begin{tabular}{|c|c|c|c|c|}
\hline & & 11 & $-14(-48,+24)$ & $+10[-158,+178]$ \\
\cline { 2 - 5 } & $31-40 \mathrm{ppb}$ & 18 & $+13(-39,+45)$ & $+15[-151,+182]$ \\
\cline { 2 - 5 } & $41-49 \mathrm{ppb}$ & 16 & $-182(-47,+50)$ & $+13[-149,+174]$ \\
\cline { 2 - 5 } & $<50 \mathrm{ppb}$ & 185 & $+2(-33,+51)$ & $-19[-90,+52]$ \\
\cline { 2 - 5 } & $>=50 \mathrm{ppb}$ & 48 & $-10(-33,+35)$ & $+17[-159,+192]$ \\
\hline
\end{tabular}


Table 3. Median and interquartile range (IQR) change in $\mathrm{F}_{\mathrm{E}} \mathrm{NO}$ during two consecutive three-month periods of stable asthma. Change was expressed as absolute change and percentage change and results are stratified by initial $\mathrm{F}_{\mathrm{E}} \mathrm{NO}$ ( $<$ or $\geq 50$ parts per billion, ppb). Stable asthma was defined as one where symptoms were controlled at the start and the end, inhaler corticosteroid dose was unchanged and there was no asthma exacerbation.

\begin{tabular}{|c|c|c|c|c|c|c|c|}
\hline & Initial $\mathrm{F}_{\mathrm{E}} \mathrm{NO}$ value & $\mathrm{N}$ & $\begin{array}{l}\text { Median (IQR) in } \\
\text { stable } 0-3 \mathrm{mo}\end{array}$ & $\begin{array}{l}\text { Median (IQR) } \\
\text { In stable 3-6mo }\end{array}$ & p-value & $\begin{array}{c}\text { Mean (SD) difference } \\
\text { [limits of agreement] in } \\
\text { stable } 0-3 \mathrm{~m}\end{array}$ & $\begin{array}{c}\text { Mean difference [limits } \\
\text { of agreement] in stable } \\
3-6 \mathrm{~m}\end{array}$ \\
\hline \multirow{3}{*}{$\begin{array}{l}\text { Absolute } \mathrm{F}_{\mathrm{E}} \mathrm{NO} \\
\text { concentration }\end{array}$} & $<50 p p b$ & 73 & $+2(-4,+8)$ & $+3(-6,+10)$ & 0.388 & $+10(34)[-56,+76]$ & $-2(31)[-63,+59]$ \\
\hline & $\geq 50 \mathrm{ppb}$ & 23 & $-12(-44,+22)$ & $+1(-24,+19)$ & 0.274 & $-12(39)[-89,+66]$ & $-1(38)[-75,+73]$ \\
\hline & All & 96 & $+1(-7,+8)$ & $+3(-8,+10)$ & 0.153 & $+5(36)[-66,+76]$ & $-2(33)[-66,+62]$ \\
\hline \multirow{3}{*}{$\begin{array}{l}\text { Percentage } \\
\text { change in } \mathrm{F}_{\mathrm{E}} \mathrm{NO}\end{array}$} & $<50 p p b$ & 73 & $+16(-24,+67)$ & $+13(-36,+77)$ & 0.555 & $+48(119)[-184,+280]$ & +42 (99) $[-153,+237]$ \\
\hline & $\geq 50 \mathrm{ppb}$ & 23 & $-11(-51,+32)$ & $+1(-30,+25)$ & 0.484 & $-7(47)[-99,+86]$ & $+6(55)[-100,+114]$ \\
\hline & All & 96 & $+8(-29,+47)$ & $+11(-35,+70)$ & 0.365 & $+35(108)[-177,+247]$ & $+33(92)[-147,+213]$ \\
\hline
\end{tabular}

\# Wilcoxon matched pairs 
Table 4. Median and interquartile range (IQR) change in $\mathrm{F}_{\mathrm{E}} \mathrm{NO}$ during a three-month period of stable asthma followed by an unstable period. Change was expressed as absolute change and percentage change and results are stratified by initial $\mathrm{F}_{\mathrm{E}} \mathrm{NO}$ ( $<$ or $\geq 50$ parts per billion, ppb).

Stable asthma was defined as one where symptoms were controlled the start and the end, inhaler corticosteroid dose was unchanged and there was no asthma exacerbation.

\begin{tabular}{|c|c|c|c|c|c|c|c|}
\hline & Initial $F_{E} N O$ value & $\mathrm{N}$ & $\begin{array}{c}\text { Median (IQR) } \\
\text { in stable } 0-3 \mathrm{m0}\end{array}$ & $\begin{array}{c}\text { Median (IQR) } \\
\text { unstable 3-6mo }\end{array}$ & $\mathrm{p}$-value $\#$ & $\begin{array}{c}\text { Mean difference (SD) } \\
\text { [limits of agreement] } \\
\text { in stable } 0-3 \text { mo }\end{array}$ & $\begin{array}{l}\text { Mean difference (SD) [limits } \\
\text { of agreement] in unstable 3- } \\
6 \mathrm{mo}\end{array}$ \\
\hline \multirow{3}{*}{$\begin{array}{l}\text { Absolute } \mathrm{F}_{\mathrm{E}} \mathrm{NO} \\
\text { concentration }\end{array}$} & $<50 p p b$ & 32 & $-1(-8,+11)$ & $+3(-12,+13)$ & 0.702 & $+6(31)[-54,+66]$ & $-3(26)[-54,+48]$ \\
\hline & $\geq 50 \mathrm{ppb}$ & 16 & $-5(-46,+17)$ & $0(-34,+18)$ & 0.255 & $-22(55)[-130,+87]$ & $-8(37)[-80,+64]$ \\
\hline & All & 48 & $-2(14,+14)$ & $+3(-13,+14)$ & 0.322 & $-4(42)[-86,+79]$ & $-4(30)[-63,+54]$ \\
\hline \multirow{3}{*}{$\begin{array}{l}\text { Percentage change } \\
\text { in } \mathrm{F}_{\mathrm{E}} \mathrm{NO}\end{array}$} & $<50 p p b$ & 32 & $-6(-30,+40)$ & $+18(-30,+65)$ & 0.736 & $+38(134)[-224,+300]$ & $+29(77)[-121,+179]$ \\
\hline & $\geq 50 \mathrm{ppb}$ & 16 & $-12(-47,+22)$ & $0(-38,+31)$ & 0.438 & $-14(40)[-92,+65]$ & $-2(45)[-91,+87]$ \\
\hline & All & 48 & $-6(-37,+25)$ & $+13(-33,+57)$ & 0.467 & $+21(114)[-202,+243]$ & $+19(69)[-116,+153]$ \\
\hline
\end{tabular}


What is a clinically meaningful change in exhaled nitric oxide for children with asthma?

Shona Fielding $\mathrm{PhD}^{1}$, Marielle Pijnenburg $\mathrm{PhD}^{2}$, Johan de Jongste $\mathrm{PhD}^{2}$, Katherine Pike $\mathrm{PhD}^{3,4}$, Graham Roberts $\mathrm{PhD}^{3}$, Helen Petsky $\mathrm{PhD}^{5}$, Anne B Chang $\mathrm{PhD}^{5}$, Maria Fritsch $\mathrm{MD}^{6}$, Thomas Frischer $\mathrm{MD}^{6}$, Stanley Szefler $\mathrm{PhD}^{7}$, Peter Gergen $\mathrm{PhD}^{8}$, Françoise Vermeulen $\mathrm{MD}^{9}$, Robin Vael $M D^{10}$, Steve Turner $\mathrm{MD}^{11}$.

${ }^{1}$ Medical Statistics Team, Institute of Applied Health Sciences, University of Aberdeen, UK

${ }^{2}$ Department of Paediatric Respiratory Medicine and Allergology, Erasmus MC - Sophia Children's Hospital, Rotterdam, Netherlands

${ }^{3}$ Clinical and Experimental Science Academic Unit, University of Southampton, Southampton, UK

${ }^{4}$ Respiratory Critical Care and Anaesthesia group, Institute of Child Health, University College London, UK

${ }^{5}$ Department of Respiratory and Sleep Medicine, Queensland's Children's Hospital, Queensland University of Technology, Brisbane; Child Health Division, Menzies School of Health Research, Charles Darwin University, Darwin, Australia

'University Children's Hospital, Vienna, Austria

${ }^{7}$ Breathing Institute, Children's Hospital Colorado, Department of Pediatrics, University of Colorado School of Medicine, Aurora, Colorado, USA

${ }^{8}$ National Institute of Allergy and Infectious Diseases, Bethesda, MD USA

${ }^{9}$ Department of Paediatrics, Hôpital Erasme, Université Libre de Bruxelles (U.L.B.), Brussels, Belgium 
${ }^{10}$ Department of Paediatrics, Antwerp University Hospital, Antwerp, Belgium

${ }^{11}$ Child Health, University of Aberdeen, UK

Corresponding author: Professor Steve Turner, Child Health, Royal Aberdeen Children's

Hospital, Aberdeen, UK, AB25 2ZG. Tel +44 1224 438470. s.w.turner@abdn.ac.uk

Keywords: Asthma, Child, Monitoring, Exhaled nitric oxide

Running head: What is a meaningful change in $\mathrm{F}_{\mathrm{E}} \mathrm{NO}$ in children? 


\begin{abstract}
Introduction. Fractional exhaled nitric oxide $\left(\mathrm{F}_{\mathrm{E}} \mathrm{NO}\right)$ may be a useful objective measurement to guide asthma treatment. What remains uncertain is what change in $\mathrm{F}_{\mathrm{E}} \mathrm{NO}$ is clinically significant.
\end{abstract}

Methods. An individual patient data analysis was performed using data from seven randomised clinical trials which used $\mathrm{F}_{\mathrm{E}} \mathrm{NO}$ to guide asthma treatment. The absolute and percentage intra-subject change in $\mathrm{F}_{\mathrm{E}} \mathrm{NO}$ measurements over "stable" and also "unstable" three-month periods were described.

Results. Data were available in 1112 RCT participants and $\geq 1$ stable period was present for 665 individuals. The interquartile range (IQR) and limits of agreement (LOA) for change in absolute $\mathrm{F}_{\mathrm{E}} \mathrm{NO}$ among individuals whose initial $\mathrm{F}_{\mathrm{E}} \mathrm{NO}$ was $<50 \mathrm{ppb}$ were -7 to $9 \mathrm{ppb}$ and -43 to $50 \mathrm{ppb}$, and for those with initial $\mathrm{F}_{\mathrm{E}} \mathrm{NO} \geq 50 \mathrm{ppb}$ IQR was -29 to $17 \mathrm{ppb}$ and LoA was -80 to 76ppb. For percentage change in $F_{E} N O$, the IQR and LoA for individuals whose initial $F_{E} N O$ was $<50 p p b$ were -33 to $51 \%$ and -157 to $215 \%$, and for those with initial $\mathrm{F}_{\mathrm{E}} \mathrm{NO} \geq 50 \mathrm{ppb}$ were -33 to $35 \%$ and -159 to $192 \%$. The variation in $\mathrm{F}_{\mathrm{E}} \mathrm{NO}$ values for a stable period was similar irrespective of whether it was followed by a stable or unstable period.

Conclusions. Over a three-month period where $\mathrm{F}_{\mathrm{E}} \mathrm{NO}$ is initially $<50 \mathrm{ppb}$, a rise of $<10 \mathrm{ppb}$ or of $<50 \%$ (based on IQR) is unlikely to be related to asthma. When $\mathrm{F}_{\mathrm{E}} \mathrm{NO}$ is initially $\geq 50 \mathrm{ppb}$ an percentage change of $<50 \%$ (based on IQR) is unlikely to be asthma-related. 


\section{INTRODUCTION}

Asthma is a very common condition and affects millions of children in the UK (1) and the US(2). There is no cure for asthma, but there is effective treatment to control asthma symptoms and reduce exacerbations. Guidelines recommend that asthma treatment is guided by symptoms(3-5), but symptom-reporting and interpretation is subjective and this leads to inconsistent care. There is a need for an objective biomarkermeasurement to allow greater consistency in asthma treatment (6).

Fractional exhaled nitric oxide $\left(\mathrm{F}_{\mathrm{E}} \mathrm{NO}\right)$ is a surrogate for airway eosinophilia $(7)$ and has potential roles in asthma including diagnosis, treatment stratification, treatment adherence and monitoring airway inflammation (7). A recent Agency for Healthcare $\underline{\text { Research and Quality comparative effectiveness review of } \mathrm{F}_{\mathrm{E}} \text { NO has summarised evidence }}$ which supports a number of potential clinical applications of $F_{E}$ NO in the management of asthma(8). $\mathrm{F}_{\mathrm{E}} \mathrm{NO}$ has many of the characteristics required of an objective tool to monitor allergic asthma over time since it rises before symptoms occur(9-11), falls when asthma treatment is administered $(12,13)$, can be measured with minimal discomfort to the patient and results are available within a few minutes using commercially-available Food and Drink Administration approved apparatus(14). When compared to standard treatment, asthma treatment guided by $\mathrm{F}_{\mathrm{E}} \mathrm{NO}$ measurements is associated with reduced asthma exacerbations, but not improved asthma control(15). There are some key questions which need to be answered before $\mathrm{F}_{\mathrm{E}} \mathrm{NO}$ can be incorporated into the routine longitudinal management of childhood asthma, and current asthma guidelines do not recommend $\mathrm{F}_{\mathrm{E}} \mathrm{NO}$ for monitoring asthma outside specialist clinics(3-5). 
One key question which needs answering is "what change in $\mathrm{F}_{\mathrm{E}} \mathrm{NO}$ is clinically relevant in children?" The American Thoracic Society (ATS) guideline proposes that a change of 10 parts per billion at lower concentrations or $20 \%$ at higher concentrations may have clinical relevance(7), but acknowledge a low level of evidence. However, one study where children with mild asthma and without asthma had repeated measurements of $\mathrm{F}_{\mathrm{E}} \mathrm{NO}$, questioned this ATS recommendation by finding that values may change by as much as $100 \%$ without any clinical change (16). A second study has reported that $\mathrm{F}_{\mathrm{E}} \mathrm{NO}$ values fluctuate between $6 \mathrm{ppb}$ and $40 \mathrm{ppb}$ in children on stable asthma treatment (17).

Our group has pooled the data collected in more than 1000 participants in seven RCTs where $\mathrm{F}_{\mathrm{E}} \mathrm{NO}$ was used to guide asthma treatment (18). This analysis found that a $50 \%$ increase in FeNO between baseline and three months was associated with $11 \%$ increase in odds for poor asthma control six months after baseline(18)but it remains unknown the degree of $\mathrm{F}_{\mathrm{E}} \mathrm{NO}$ variability over stable and unstable periods. Thus, we used individual patient data from the same database of seven RCTs to address the question "What is the variability in $\mathrm{F}_{\mathrm{E}} \mathrm{NO}$ over three months among children with stable asthma?".

\section{METHODS}

\section{Study design}

Authors of published RCTs which used $\mathrm{F}_{\mathrm{E}} \mathrm{NO}$ to guide asthma treatment in children(15) were asked to provide data, as described-previously described (18), provided de-identified data for analyses in this study. All RCTs collected details of $F_{E} N O$ concentrations, asthma control (using different scores) and exacerbation outcome (defined 
as requiring oral corticosteroid treatment) at each assessment. $\mathrm{F}_{\mathrm{E}} \mathrm{NO}$ was measured in all studies in accordance with the American Thoracic Society 2005 guideline(19). Percentage of predicted (\%) $\mathrm{FEV}_{1}$ was standardised to the Global Lung Initiative reference (20) with the exception of two trials $(21,22)$ where only $\% \mathrm{FEV}_{1}$ standardised to other references was available. Covariates collected at baseline in all trials included: age, gender, height, weight, trial arm, dose of inhaled corticosteroid (ICS, as daily budesonide equivalent dose, BUD), prescribed long acting beta agonist (LABA) or not, prescribed leukotriene receptor agonist (LTRA) or not, and an asthma control score. Institutional ethical approval was provided for each trial which contributed data.

\section{Details of each population}

Fritsch et al(23). In this study, 47 children were recruited from a hospital asthma clinic in Vienna, Austria. Data were collected at six-week intervals over six months.

Peirsman et al(24). Researchers in centres across Belgium recruited 99 participants with persistent asthma attending hospital asthma clinics. Clinical assessments took place every three months over one year.

Petsky et al(25). Children in Australia and Hong Kong were recruited from hospital clinics. There were 63 patients enrolled and clinical assessment took place on eight occasions over twelve months (one, two, three, four, six, eight, ten and twelve months). The ten-month assessment was assigned the "nine month" assessment for the present analysis.

Pijnenburg et al (21). This study was carried out in the Netherlands and 86 patients were recruited and followed up at three-month periods over one year.

Pike et al (22). This was a study carried out in Southampton, UK and 90 patients were recruited and followed up at two-month intervals over twelve months. The two- 
month assessment was assigned the "three month" assessment for the analysis, also the ten-month was assigned the "nine month" assessment.

Szefler et al(26). Children and young adults of African or Hispanic descent and living in inner city areas of ten US cities were recruited. There were 546 participants and data were collected at the following intervals post randomisation: 6 weeks, 14 weeks (used in lieu of three months in the analysis), 22 weeks (used in lieu of six months), 30 weeks (used in lieu of nine months) and 46 weeks (used in lieu of twelve months).

Voorend-van Bergen et al(27). This RCT took place in the Netherlands and 181 participants were recruited. Data from a third arm of the RCT which delivered a web-based intervention were not included in the present analysis. Data were collected at four-month intervals over a year. The four and eight month assessments were respectively assumed to be three and six month assessment for the analysis. There was no equivalent nine-month assessment.

\section{Analysis}

Participants were identified as having a three-month period of stable asthma if they had a period between two successive assessments over three months during which: (i) asthma was controlled at the beginning and end (different RCTs used different scoring systems) (ii) the dose of inhaled corticosteroid (ICS) remained unchanged and (iii) there was no exacerbation requiring oral corticosteroid treatment. Change in $\mathrm{F}_{\mathrm{E}} \mathrm{NO}$ values was expressed as either an absolute difference or percentage difference over a three month period and as either the mean and $95 \%$ limits of agreement (LOA) or median and interquartile range (IQR). Change in $\mathrm{F}_{\mathrm{E}} \mathrm{NO}$ could not be expressed as geometric mean since 
values can be negative (16). Change in $\mathrm{F}_{\mathrm{E}} \mathrm{NO}$ was described for all individuals and also stratified for individuals with initial values of $<50 \mathrm{ppb}$ and $\geq 50 \mathrm{ppb}$ for comparison with the guideline (7) and also for ranges <11ppb, 11-20ppb, 21-30ppb, 31-40ppb and 41-49ppb to allow comparison with data from ał study by Cutts et al (16)which recruited children with no asthma and mild asthma(16). One author of the present paper (ST) is data custodian for the study (16) and reanalysed the data for direct comparison between studies. For patients with multiple stable periods, data from only the first stable period was included. To determine whether $\mathrm{F}_{\mathrm{E}} \mathrm{NO}$ values during a stable period were influenced by a subsequent unstable period we described change in $\mathrm{F}_{\mathrm{E}} \mathrm{NO}$ values during; (i) successive stable periods (i.e. when the child's asthma was controlled for three successive assessment, had no change in ICS dose and did not have an exacerbation) and (ii) also a stable followed by an unstable period (i.e. when the child's asthma was controlled for two successive assessments during which there was no change in ICS dose or an exacerbation but where asthma was uncontrolled on the third assessment. An unstable period was defined as one where asthma control was present but became lost and and where ICS dose remained unchanged. Comparisons we made using Wilcoxon signed rank test.

\section{RESULTS}

\section{Study subjects}

Data from 1112 participants in seven RCT were analysed (21-27). Participant details at baseline are presented in table one and have also been described elsewhere (18). The mean (SD) participant age was 12.6 (3.1) years and 58\% of participants were male.

\section{Variability of $\mathrm{F}_{\mathrm{E}} \mathrm{NO}$ within stable three months periods}


All stable individuals. There were 251 children who had a total of 260 three-month intervals where asthma was stable. Due to missing $\mathrm{F}_{\mathrm{E}} \mathrm{NO}$ values in 16 individuals, change in $\mathrm{F}_{\mathrm{E}} \mathrm{NO}$ could be calculated in 235 participants with an overall median (IQR) absolute $\mathrm{F}_{\mathrm{E}} \mathrm{NO}$ change $-0.5 p p b(-9,10)$, and percentage $F_{E} N O$ change $-2 \%(-33 \%, 50 \%)$. For all stable participants combined, the mean (limits of agreement) for change in absolute $\mathrm{F}_{\mathrm{E}} \mathrm{NO}$ was +2 ppb $(-52,+56)$ and for percentage change $\mathrm{F}_{\mathrm{E}} \mathrm{NO}$ was $+26 \%(-157,+210)$.

Stable and initial $F_{E} N O<50 p p b$. The 185 children with stable asthma and baseline $\mathrm{F}_{\mathrm{E}} \mathrm{NO}<50 \mathrm{ppb}$ had a median (IQR) absolute change in $\mathrm{F}_{\mathrm{E}} \mathrm{NO} 0 \mathrm{ppb}(-7,+9)$ and the median (IQR) percentage change in $\mathrm{F}_{\mathrm{E}} \mathrm{NO}$ was $+2 \%(-33,+51)$, table 2 . The mean (LoA) change in absolute $\mathrm{F}_{\mathrm{E}} \mathrm{NO}$ was $+3(-43,+50)$ and the mean (LoA) percentage change was $+29(-157$, $+215)$, table 2.

Stable and initial $F_{E} N O \geq 50 p p b$. Where baseline $F_{E} N O$ was $\geq 50 p p b(n=48)$, the median values (IQR) for absolute and percentage change in $\mathrm{F}_{\mathrm{E}} \mathrm{NO}$ were $-7 \mathrm{ppb}(-29,+17)$ and $-10 \%(-33,+35)$ respectively, table 2 . The mean (LoA) for change in absolute $\mathrm{F}_{\mathrm{E}} \mathrm{NO}$ was -2 ppb $(-80,+76)$ and for percentage change $F_{E} N O$ was $+17 \%(-159,+192)$, see table 2

Stable and initial $F_{E} N O$ stratified for comparison with Cutts et al (16). Table 2 presents absolute and percentage change in $\mathrm{F}_{\mathrm{E}} \mathrm{NO}$ expressed as mean (LOA) and median (IQR) using data collected from children with asthma recruited to the RCTs. Data from the study of mostly healthy children by Cutts et al (16) are also presented for comparison. 
There were 96 individuals with two consecutive periods of stable asthma. The median (IQR) $\mathrm{F}_{\mathrm{E}} \mathrm{NO}$ concentrations during the first and second stable periods were $+1 \mathrm{ppb}$ ($7,+8)$ and $+3 p p b(-8,+10)$; corresponding percentage change $\mathrm{F}_{\mathrm{E}} \mathrm{NO}$ values were $+8(-29,+47)$ and $+11(-35,+70)$, see table 3 . Table 3 also presents results after stratification by $<50 p p b$ and $\geq 50 \mathrm{ppb}$. There was no differences in change in $\mathrm{F}_{\mathrm{E}} \mathrm{NO}$ between the first and second stable periods.

\section{During consecutive periods of stable asthma followed by unstable asthma}

There were 48 individuals identified. The median (IQR) change in absolute $\mathrm{F}_{\mathrm{E}} \mathrm{NO}$ values during stable and unstable periods were $-2(-14,+14)$ and $3(-13,14)$ and percentage change during stable and unstable periods were $-6(-37,+25)$ and $13(-33,+57)$, see table 4 . Table 4 presents results stratified by $<50 \mathrm{ppb}$ and $\geq 50 \mathrm{ppb}$. There was no differences in change in $\mathrm{F}_{\mathrm{E}} \mathrm{NO}$ between the stable and unstable periods.

\section{DISCUSSION}

\section{Fractional exhaled nitric oxide has a number of potential roles in asthma and the}

focus of the present study This analysis aim-was to answer the question "What is a clinically significant change in $\mathrm{F}_{\mathrm{E}} \mathrm{NO}$ for children with asthma?" Our results may be relevant to clinicians when interpreting repeated $\mathrm{F}_{\mathrm{E}} \mathrm{NO}$ measurements, e.g. when making treatment decisions in a child with already-diagnosed asthma. The premise underlying our analysis was that any change in $\mathrm{F}_{\mathrm{E}} \mathrm{NO}$ which occurred in children during a period of stability was not 
clinically relevant. Our first finding was that when applying a stringent threshold of the LoA (i.e. including $95 \%$ of all values), the variability in $\mathrm{F}_{\mathrm{E}} \mathrm{NO}$ during stability was extremely wide and thus likely to include clinically significant events (i.e. loss of control and/or exacerbation). In contrast when applying the more liberal threshold of IQR (i.e including $50 \%$ of all values), the upper limit of variability could be applied clinically. Indeed the upper quartile value for participants with $\mathrm{F}_{\mathrm{E}} \mathrm{NO}<50 \mathrm{ppb}$ was $<10 \mathrm{ppb}$ and consistent with the ATS recommendation (7).

Our second finding was that expressing change in $\mathrm{F}_{\mathrm{E}} \mathrm{NO}$ as percentage change lead to a consistent IQR of between $\pm 50 \%$ for all initial $F_{E} N O$ values. The upper quartile value for $\%$ change where the initial $\mathrm{F}_{\mathrm{E}} \mathrm{NO}$ was $>50 \mathrm{ppb}$ was $35 \%$, but having a "one size fits all" recommendation (i.e. $<50 \%$ is unlikely to be clinically relevant) could be more easily understood by patients and health care staff, and also would facilitate management for individuals whose $\mathrm{F}_{\mathrm{E}} \mathrm{NO}$ is close to $50 \mathrm{ppb}$ (the current dichotomy for different recommendations in the ATS guideline(7)). Our results do not support the ATS "weak" recommendation that a change of $>20 \%$ may be clinically meaningful for children with $\mathrm{F}_{\mathrm{E}} \mathrm{NO} \geq 50 \mathrm{ppb}(7)$

The IQR and LoA from the present study are consistent with a study where $F_{E} N O$ was measured at two month intervals over a year in children with mild or no asthma, where it was found that initial $F_{E} N O$ values may rise by up to $100 \%(16)$. This consistency is despite important differences between our present study and that of Cutts et al (16), for example our study had a relatively greater number of participants with asthma, higher median $\mathrm{F}_{\mathrm{E}} \mathrm{NO}$ values and $\mathrm{F}_{\mathrm{E}} \mathrm{NO}$ measurements were repeated over a three month period compared to two months. For everyday clinical practice it is more relevant to define clinically relevant 
changes in $\mathrm{F}_{\mathrm{E}} \mathrm{NO}$ in a population of asthmatic children who are treated with ICS as compared to healthy children or steroid naive children.

Considerable variation in $\mathrm{F}_{\mathrm{E}} \mathrm{NO}$ values over time has also been reported in "natural experiments" in children. For example Huss-Marp et al(28) observed that $\mathrm{F}_{\mathrm{E}} \mathrm{NO}$ values in children with mild intermittent asthma with initial $\mathrm{F}_{\mathrm{E}} \mathrm{NO}>17 \mathrm{ppb}$ and attending a summer camp at altitude fell by $50 \%$ over four to six weeks independent of symptoms, and Kaminsky et al (29) found $\mathrm{F}_{\mathrm{E}} \mathrm{NO}$ values fell from 11 to $6 \mathrm{ppb}$ (a $45 \%$ reduction) independent of asthma control among 27 children attending a one week summer camp. Two studies of children with asthma who were sensitised to grass found the $\mathrm{F}_{\mathrm{E}} \mathrm{NO}$ values rose by approximately $50 \%$ during the pollen season $(30,31)$ but asthma symptoms also rose during this time. Barreto et al (32) found that the coefficient of variation in paired $\mathrm{F}_{\mathrm{E}} \mathrm{NO}$ values taken over a one-week period was $3 \mathrm{ppb}$ in eight children treated with ICS. Due to the limited literature describing change in $\mathrm{F}_{\mathrm{E}} \mathrm{NO}$ over time, these studies provide some useful insight into the variability of $\mathrm{F}_{\mathrm{E}} \mathrm{NO}$ but they are limited since some of the variability will be explained by changes in the children's environment.

Within our pooled dataset we were able to explore whether variability in a stable period was different if it was followed by either stability or instability. We found no evidence that repeated measurements of $\mathrm{F}_{\mathrm{E}} \mathrm{NO}$ over three month intervals were influenced by subsequent control, and this is consistent with studies where daily $\mathrm{F}_{\mathrm{E}} \mathrm{NO}$ measurements were made and which observed rising $\mathrm{F}_{\mathrm{E}} \mathrm{NO}$ over only 3-7 days before an exacerbation $(11,17)$. The typical change in $\mathrm{F}_{\mathrm{E}} \mathrm{NO}$ in the studies where daily measurements were obtained was $<50 \%(11,17)$, and the relatively rapid and short-lived peak in $\mathrm{F}_{\mathrm{E}} \mathrm{NO}$ in the context of an asthma exacerbation would indicate that $\mathrm{F}_{\mathrm{E}} \mathrm{NO}$ was not likely to be useful in reducing 
exacerbation risk, but evidence from RCTs indicates that $\mathrm{F}_{\mathrm{E}} \mathrm{NO}$-guided treatment more effective than standard care in reducing exacerbations (15). Despite the "noisy signal" that is evidenced by the considerable variability in both daily $(11,17)$ and three-monthly (the present study) $\mathrm{F}_{\mathrm{E}}$ NO measurements, there seems to be sufficient clinically relevant change in $\mathrm{F}_{\underline{E}} \underline{\mathrm{NO}}$ over time for $\mathrm{F}_{\underline{E}} \underline{\mathrm{NO}}$-guided treatment to be associated with reduced exacerbations(15).

Our study has a number of limitations. First, the protocols of some of the RCTs included had intervals other than three months between repeated $\mathrm{F}_{\mathrm{E}} \mathrm{NO}$ measurements and this may have added greater variability into repeated measurements. Compared to the study by Cutts et al (16), the IQR for percentage change in the present study was relatively larger but the absolute change was relatively smaller than results so this argues against an interval of two months leading to variation which is substantially greater than for a three month interval. Second, we have no index of treatment adherence, and it is likely that some variation in repeated $\mathrm{F}_{\mathrm{E}} \mathrm{NO}$ measurements was due to incomplete adherence with ICS (12)and/or LTRA (33)treatment. Third the number of participants with stable followed by unstable asthma was relatively small and our analysis comparing intrasubject change in $\mathrm{F}_{\mathrm{E}} \mathrm{NO}$ during these two periods was probably underpowered. A further limitation of our work is that very few individuals were non-atopic and we did not stratify for variability in $\underline{F_{E}}$ NO by atopic status.

In summary, we interpret our data as showing that a percentage change in $\mathrm{F}_{\mathrm{E}} \mathrm{NO}$ of $<50 \%$ over a three-month period is unlikely to be clinically relevant in a child with controlled asthma whatever their initial $\mathrm{F}_{\mathrm{E}} \mathrm{NO}$ concentration is. $\underline{\mathrm{F}}_{\mathrm{E}} \mathrm{NO}$ is currently used in clinical practice by many subspecialists in the initial assessment of asthma, endotyping, assessment 
of adherence and for -longitudinal monitoring. Key questions remain to be answered before $\mathrm{F}_{\mathrm{E}} \mathrm{NO}$ might be incorporated into clinical practice to justify a more widespread incorporation into clinical practise, key questions remain to be answered, including "should $\mathrm{F}_{\mathrm{E}} \mathrm{NO}, \mathrm{FEV}_{1}$ and an objective index of treatment adherence all be part of the assessment of children with asthma?" And "what specific treatment changes should be guided by changes in $\mathrm{F}_{\mathrm{E}} \mathrm{NO} ?_{-}^{\prime \prime}$ 


\section{REFERENCES}

(1) Asthma UK. Asthma facts and FAQs. 2017; Available at: http://www.asthma.org.uk/asthma-facts-and-statistics. Accessed 08/31, 2017.

(2) Centers for Disease Control and Prevention. Asthma. Most recent data. 2016; Available at: https://www.cdc.gov/asthma/most recent data.htm. Accessed 08/31, 2017.

(3) British Thoracic Society and Scottish Intercollegiate Guidelines Network. SIGN 158. The British Guideline on the Management of Asthma. 2019; Available at: https://www.britthoracic.org.uk/quality-improvement/guidelines/asthma/. Accessed 07/27, 2019.

(4) Global Initiative for Asthma. Global Strategy for Asthma Management and Prevention. 2019; Available at: https://ginasthma.org/gina-reports/. Accessed 07/26, 2019.

(5) National Institute for Health and Care Excellence. Asthma: diagnosis, monitoring and chronic asthma management. 2017; Available at: https://www.nice.org.uk/guidance/ng80. Accessed 01/28, 2018.

(6) Pavord ID, Beasley R, Agusti A, Anderson GP, Bel E, Brusselle G, Cullinan P, Custovic A, Ducharme FM, Fahy JV, Frey U, Gibson P, et al. After asthma: redefining airways diseases. Lancet 2018;391:350-400.

(7) Dweik RA. Boggs PB. Erzurum SC. Irvin CG. Leigh MW. Lundberg JO. Olin AC. Plummer AL. Taylor DR. American Thoracic Society Committee on Interpretation of Exhaled Nitric Oxide Levels (FENO) for Clinical Applications. An official ATS clinical practice guideline:

interpretation of exhaled nitric oxide levels (FENO) for clinical applications. Am J Respir Crit Care Med 2011 Sep 1;184(5):602-615.

(8) Wang Z, Pianosi PT, Keogh KA, Zaiem F, Alsawas M, Alahdab F,Almasri J, Mohammed K, Larrea-Mantilla L, Farah W, et al. The Diagnostic Accuracy of Fractional Exhaled Nitric Oxide Testing in Asthma: A Systematic Review and Meta-analyses. Mayo Clin Proc 2018;93(2):191198.

(9) Pijnenburg MW, Hofhuis W, Hop WC, De Jongste JC. Exhaled nitric oxide predicts asthma relapse in children with clinical asthma remission. Thorax 2005 Mar;60:215-218.

(10) Zacharasiewicz A, Wilson N, Lex C, Erin EM, Li AM, Hansel T, Khan M, Bush A. Clinical use of noninvasive measurements of airway inflammation in steroid reduction in children. Am J Respir Crit Care Med 2005 May 15;171:1077-1082.

(11) van der Valk, R J P., Baraldi E, Stern G, Frey U, de Jongste JC. Daily exhaled nitric oxide measurements and asthma exacerbations in children. Allergy 2012 Feb;67:265-271.

(12) Beck-Ripp J, Griese M, Arenz S, Koring C, Pasqualoni B, Bufler P. Changes of exhaled nitric oxide during steroid treatment of childhood asthma. Eur Respir J 2002 Jun;19(6):10151019. 
(13) Baraldi E, Azzolin NM, Zanconato S, Dario C, Zacchello F. Corticosteroids decrease exhaled nitric oxide in children with acute asthma. J Pediatr 1997 Sep;131:381-385.

(14) Silkoff PE, Carlson M, Bourke T, Katial R, Ogren E, Szefler SJ. The Aerocrine exhaled nitric oxide monitoring system NIOX is cleared by the US Food and Drug Administration for monitoring therapy in asthma. J Allergy Clin Immunol 2004 Nov;114:1241-1256.

(15) Petsky HL, Kew KM, Chang AB. Exhaled nitric oxide levels to guide treatment for children with asthma. Cochrane Database of Systematic Reviews 2016(11):Art. No.: CD011439. DOI: 10.1002/14651858.CD011439.pub2.

(16) Cutts R, Turner S. Longitudinal measurements of exhaled nitric oxide in children-what is a significant change in FE(NO) ?. Pediatr Allergy Immunol 2013;24:540-548.

(17) Stern G, de Jongste J, van der Valk R, Baraldi E, Carraro S, Thamrin C, Frey U. Fluctuation phenotyping based on daily fraction of exhaled nitric oxide values in asthmatic children. $J$ Allergy Clin Immunol 2011;128:293-300.

(18) Fielding S, Pijnenburg M, de Jongste JC, Pike K, Roberts G, Petsky H, Chang AB, Fritsch $M$, Frischer T, Szefler S, et al. Change in FEV1 and FENO Measurements as Predictors of Future Asthma Outcomes in Children. Chest 2019;155:331-341.

(19) American Thoracic Society, European Respiratory Society. ATS/ERS recommendations for standardized procedures for the online and offline measurement of exhaled lower respiratory nitric oxide and nasal nitric oxide, 2005. Am J Respir Crit Care Med 2005;171:912-930.

(20) Quanjer PH, Stanojevic S, Cole TJ, Baur X, Hall GL, Culver BH, Enright PL, Hankinson JL, Ip MS, Zheng J, et al. Multi-ethnic reference values for spirometry for the 3-95-yr age range: the global lung function 2012 equations. Eur Respir J 2012;40:1324-1343.

(21) Pijnenburg MW, Bakker EM, Hop WC, De Jongste JC. Titrating steroids on exhaled nitric oxide in children with asthma: a randomized controlled trial. Am J Respir Crit Care Med 2005 ;172:831-836.

(22) Pike K, Selby A, Price S, Warner J, Connett G, Legg J, Lucas JS, Peters S, Buckely H, Magier $\mathrm{K}$, et al. Exhaled nitric oxide monitoring does not reduce exacerbation frequency or inhaled corticosteroid dose in paediatric asthma: a randomised controlled trial. Clin Respir J 2013;7:204-213.

(23) Fritsch M, Uxa S, Horak FJ, Putschoegl B, Dehlink E, Szepfalusi Z, Frischer T. Exhaled nitric oxide in the management of childhood asthma: a prospective 6-months study. Pediatr Pulmonol 2006;41:855-862.

(24) Peirsman EJ, Carvelli TJ, Hage PY, Hanssens LS, Pattyn L, Raes MM, Sauer KA, Vermeulen F, Desager KN. Exhaled nitric oxide in childhood allergic asthma management: a randomised controlled trial. Pediatr Pulmonol 2014;49:624-631. 
(25) Petsky HL, Li AM, Au CT, Kynaston JA, Turner C, Chang AB. Management based on exhaled nitric oxide levels adjusted for atopy reduces asthma exacerbations in children: $A$ dual centre randomized controlled trial. Pediatr Pulmonol 2015;50:535-543.

(26) Szefler SJ, Mitchell H, Sorkness CA, Gergen PJ, O'Connor GT, Morgan WJ, Kattan M, Pongracic JA, Teach ST, Bloomberg GR, et al. Management of asthma based on exhaled nitric oxide in addition to guideline-based treatment for inner-city adolescents and young adults: a randomised controlled trial. Lancet 2008;372:1065-1072.

(27) Voorend-van Bergen S, Vaessen-Verberne AA, Brackel HJ, Landstra AM, van den Berg NJ, Hop WC, de Jongste JC, Merkus PJ, Pijnenburg MW. Monitoring strategies in children with asthma: a randomised controlled trial. Thorax 2015;70:543-550.

(28) Huss-Marp J, Kramer U, Eberlein B, Pfab F, Ring J, Behrendt H, Gulyas AF. Reduced exhaled nitric oxide values in children with asthma after inpatient rehabilitation at high altitude. J Allergy Clin Immunol 2007;120:471-472.

(29) Kaminsky DA, Rice AA, Bissonette M, Larose T, Phillips L, Cohen L, Lahiri T, Frankowski B. Exhaled nitric oxide decreases in association with attendance at an asthma summer CAMP. J Asthma 2008;45:415-419.

(30) Roberts G, Hurley C, Bush A, Lack G. Longitudinal study of grass pollen exposure, symptoms, and exhaled nitric oxide in childhood seasonal allergic asthma. Thorax 2004;59:752-756.

(31) Baraldi E, Carra S, Dario C, Azzolin N, Ongaro R, Marcer G, Zachello F. Effect of natural grass pollen exposure on exhaled nitric oxide in asthmatic children. Am J Respir Crit Care Med 1999;159:262-266.

(32) Barreto M, Rennerova Z, Montesano M, Alterio A, Trubacova D, Ronchetti R, Villa MP. Variations in exhaled nitric oxide in children with asthma during a 1-week stay in a mountain village sanatorium. J Asthma 2008;45:453-458.

(33) Montuschi P, Mondino C, Koch P, Barnes PJ, Ciabattoni G. Effects of a leukotriene receptor antagonist on exhaled leukotriene E4 and prostanoids in children with asthma. J Allergy Clin Immunol 2006;118:347-353. 
Table 1. This table presents çCharacteristics of study participants at their baseline visit for in each study and also summarises characteristics across all studies combined. ${ }^{*}$ Controlled status was determined from questionnaires used in each study.

\begin{tabular}{|c|c|c|c|c|c|c|c|c|c|}
\hline & & $\begin{array}{l}\text { Fritsch(Fritsc } \\
\text { h et al., 2006) }\end{array}$ & $\begin{array}{l}\text { Peirsman(Pei } \\
\text { rsman et al., } \\
\text { 2014) }\end{array}$ & $\begin{array}{l}\text { Petsky(Petsk } \\
\text { y, Helen L. et } \\
\text { al., 2015) }\end{array}$ & $\begin{array}{l}\text { Pijnenburg(Pi } \\
\text { jnenburg, } \\
\text { Marielle W. } \\
\text { et al., 2005) }\end{array}$ & $\begin{array}{l}\text { Pike(Pike et } \\
\text { al., 2013) }\end{array}$ & $\begin{array}{l}\text { Szefler(Szefle } \\
\text { r et al., 2008) }\end{array}$ & $\begin{array}{l}\text { Voorend-van } \\
\text { Bergen(Voor } \\
\text { end-van } \\
\text { Bergen S et } \\
\text { al., 2015) }\end{array}$ & $\begin{array}{l}\text { All populations } \\
\text { combined }\end{array}$ \\
\hline \multicolumn{2}{|c|}{$\%$ male (number/all participants } & $60 \%(28 / 47)$ & $67 \%(66 / 99)$ & $49 \%(31 / 63)$ & $65 \%(56 / 86)$ & $57 \%(51 / 90)$ & $\begin{array}{c}53 \% \\
(288 / 546) \\
\end{array}$ & $\begin{array}{c}68 \% \\
(123 / 181) \\
\end{array}$ & $\begin{array}{c}58 \% \\
(643 / 1112) \\
\end{array}$ \\
\hline \multicolumn{2}{|c|}{ Mean age (SD), y } & $11.5(3.1)$ & $10.7(2.1)$ & $10.0(3.2)$ & $12.3(2.8)$ & $10.9(2.6)$ & $14.4(2.1)$ & $10.2(3.0)$ & $12.6(3.1)$ \\
\hline \multicolumn{2}{|c|}{ Median $\mathrm{F}_{\mathrm{E}} \mathrm{NO}$ (IQR), ppb } & $\begin{array}{c}34(18.6, \\
58.6) \\
n=46\end{array}$ & $\begin{array}{c}31(14,69) \\
n=49\end{array}$ & $\begin{array}{c}26(12.2 \\
47.5) n=61\end{array}$ & $\begin{array}{c}32(16.6 \\
52.5) n=86\end{array}$ & $\begin{array}{c}26(10,48) \\
n=90\end{array}$ & $\begin{array}{c}20(11.2 \\
40.6) \\
n=546\end{array}$ & $\begin{array}{c}18(10.2 \\
30.4) n=179\end{array}$ & $\begin{array}{c}22(11.6,43.0) \\
n=1057\end{array}$ \\
\hline \multicolumn{2}{|c|}{ Mean $\%$ predicted $\mathrm{FEV}_{1}(\mathrm{SD})$} & $\begin{array}{c}93.5(15.7) \\
n=47\end{array}$ & $\begin{array}{c}91.4(15.7) \\
\mathrm{n}=98\end{array}$ & $\begin{array}{c}90.7(15.6) \\
n=54\end{array}$ & $\begin{array}{c}97.5(17.5) \\
n=86\end{array}$ & $\begin{array}{c}89.2(14.3) \\
n=90\end{array}$ & $\begin{array}{c}90.9(16.6) \\
n=546\end{array}$ & $\begin{array}{c}93.8(13.0) \\
n=157\end{array}$ & $\begin{array}{c}93.5(18.1) \\
\mathrm{n}=1078\end{array}$ \\
\hline \multicolumn{2}{|c|}{$\%$ with positive skin prick test } & $\begin{array}{l}\text { Inclusion } \\
\text { criterion }\end{array}$ & $\begin{array}{l}\text { Inclusion } \\
\text { criterion }\end{array}$ & $\begin{array}{c}38 \% \\
(24 / 63)\end{array}$ & $\begin{array}{l}\text { Inclusion } \\
\text { criterion }\end{array}$ & $\begin{array}{c}76 \% \\
(68 / 90) \\
\end{array}$ & $\begin{array}{c}88 \% \\
(467 / 531)\end{array}$ & $\begin{array}{l}\text { Inclusion } \\
\text { criterion }\end{array}$ & $\begin{array}{c}89 \% \\
(972 / 1097)\end{array}$ \\
\hline \multirow[t]{3}{*}{$\begin{array}{l}\text { Asthma } \\
\text { medicatio } \\
n\end{array}$} & $\begin{array}{l}\text { Median dose of } \\
\text { inhaled } \\
\text { corticosteroids } \\
\text { (IQR) }\end{array}$ & $\begin{array}{l}400 \\
(0,800)\end{array}$ & $\begin{array}{l}320 \\
(200,400)\end{array}$ & $\begin{array}{l}400 \\
(250,500)\end{array}$ & $\begin{array}{l}800 \\
(400,1000)\end{array}$ & $\begin{array}{l}800 \\
(400,1000)\end{array}$ & $\begin{array}{l}1000 \\
(400,2000)\end{array}$ & $\begin{array}{l}400 \\
(400,800)\end{array}$ & $\begin{array}{l}400 \\
(400,1000)\end{array}$ \\
\hline & $\%$ prescribed LTRA & $28 \%(13 / 47)$ & $60 \%(59 / 99)$ & $10 \%(6 / 58)$ & $0 \%(0 / 86)$ & $51 \%(46 / 90)$ & $15 \%(80 / 546)$ & $13 \%(23 / 181)$ & $\begin{array}{l}21 \% \\
(227 / 1107)\end{array}$ \\
\hline & $\%$ prescribed LABA & $38 \%(18 / 47)$ & $32 \%(32 / 99)$ & $67 \%(39 / 58)$ & $38 \%(33 / 86)$ & $76 \%(68 / 90)$ & $\begin{array}{l}66 \% \\
(360 / 546)\end{array}$ & $46 \%(84 / 181)$ & $\begin{array}{l}57 \% \\
(634 / 1107)\end{array}$ \\
\hline \multicolumn{2}{|c|}{ Controlled* } & $49 \%(23 / 47)$ & $75 \%(49 / 65)$ & $72 \%(41 / 57)$ & $57 \%(44 / 77)$ & $97 \%(87 / 90)$ & $\begin{array}{l}80 \% \\
(421 / 528)\end{array}$ & $\begin{array}{l}67 \% \\
(122 / 181)\end{array}$ & $\begin{array}{l}75 \% \\
(787 / 1045)\end{array}$ \\
\hline
\end{tabular}

$\mathrm{SD}=$ standard deviation, $\underline{\mathrm{F}}_{\underline{E}} \mathrm{NO}=$ fractional exhaled nitric oxide, ppb=parts per billion, $\mathrm{FEV}_{1}=$ Forced exhaled volume in one second,

$\mathrm{IQR}=$ interquartile range, LTRA=leukotriene receptor antagonist, LABA=long acting beta agonist 